\author{
Adam Płachciak \\ Wrocław University of Economics \\ Faculty of Economy, Management and Tourism in Jelenia Góra \\ e-mail: adam.plachciak@ue.wroc.pl
}

\title{
Sen's concept of development as freedom and the idea of sustainable development ${ }^{*}$
}

\begin{abstract}
On the one hand, the contemporary world is a place of sheer abundance; on the other, it is a place where the poverty is widespread, people's needs are unsatisfied, and the natural and socioeconomic systems remain unstable. The negligence/absence of human rights and basic political needs pose a direct threat to development. One of the most effective answers to such a threat is the idea of sustainable development, which works towards the goal of satisfying the needs of present generations without depriving the future generations of their options and basic needs. Amartya Sen's concept of development, understood as a process of extending basic civil rights and freedoms as well as improving the effectiveness of social security networks is crucial for intellectual reflection on the idea of sustainable development.
\end{abstract}

Keywords: freedom, development, responsibility, natural environment, sustainable development

JEL Classification: P3, J0, Z10

\footnotetext{
* The article is an updated version of the paper published in Polish in the Annales. Ethics in Economic Life, 13(1), 149-156.
} 


\section{Introduction}

The world we live in offers us abundance that we have never experienced before, but it is also full of misery, humiliation and oppression. The emerging problems add to the existing ones: structural poverty, hunger and chronic malnutrition, disregard for basic human rights and political freedoms, increasing threats to the natural environment, instability of economic and social life, etc. For the modern civilization to be structured and function properly, it is indispensable to grant the civil liberties to individuals, especially having a say in the creation of law so that the world could become transparent, predictable, subject to remodelling, and above all, friendly to people and the natural surroundings.

In response to modern civilization threats, the idea of sustainable development recognizes the necessity of encouraging such development which would satisfy the current needs of people, without depriving the future generations of the possibility for satisfying theirs. Achieving the above assumptions requires, among other things, eliminating the main sources of unfreedom, such as poverty, limited economic opportunities, lack of social security, intolerance or speciesism. Only free people can make choices that are optimal when it comes to the purpose of their existence and the forms of social organization, to keep the natural environment clean and healthy, and to control the growth of economic profit while respecting human rights and the principles of civil society.

It seems reasonable that Amartya Sen's understanding of developmentnamely the process of extending civil liberties and political freedoms, of enhancing the effectiveness of social safety net, and of increasing the social subjectivity, etc. - is to be associated with the model of sustainable society.

Nonetheless, it should be also remembered that the triumph of global capitalism, which adopted the concept of freedom as one of its slogans, led to the situation in which half of the 100 countries with the most developed economies are centrally planned, while the goal of such economic planning is the profit that ultimately goes into the pockets of just $1 \%$ of the wealthiest people of the world. Let us begin our deliberations by looking at the basic contradictions in the neoliberal concept of freedom.

\section{Neoliberal newspeak about freedom}

Neoliberalism emerged in the background of public policy in the late 1940s as a potential antidote for the threats to the capitalist order. In 1947, a small group of academic economists, historians and philosophers centred around Friedrich von Hayek founded the Mont Pelerin Society-named after the location of the Swiss resort in which its first meeting took place. Due to attachment to the ideals of personal freedom, the members of the group sought to draw on the traditional liberalism in its European sense. In practice, however, neoliberalism turned out to 
be closer to the free-market principles of neoclassical economics that were formulated in the second half of the $19^{\text {th }}$ century thanks to the works of Alfred Marshall, William Stanley Jevons and Léon Walras, and eventually rejected the classical economic theories of Adam Smith, David Ricardo and, of course, Karl Marx. Neoliberals remained faithful only to Adam Smith's theory of the invisible hand that operates in the market, starting from which they could advance their thesis that the expansion of economic capital is beneficial to all economic subjects in accordance with the principle of benefits "trickling down" to lower social strata, and so they could dispel possible moral doubts. Consequently, the doctrine of neoliberalism was clearly contrary to the Keynesian theory of the welfare state, which gained special attention in the 1930 s as a response to the recession during the Great Depression (Harvey, 2008, p. 31).

The neoliberal concept of freedom takes on an extremely individualistic form and is considered in three interrelated and complementary ways (Bihr, 2008, pp. 138-139). First of all, it concerns economic freedom. Neoliberals believe that the world is based on the unlimited private property, while a goal of the free market mechanism is to create opportunities for becoming richer by serving a consumer in the best and cheapest way possible. To optimize the satisfaction of citizens' needs and to readily supply them with what they want, a rational economy is required, which in turn depends on the private property in its capitalistic version. The interests of entrepreneurs should always coincide with the interests of consumers. The better they anticipate customers' needs, the more prosperous they get (Mises, 1989, pp. 142-143). Yet, as sarcastically stated by Zygmunt Bauman, capitalism

is essentially a parasitic system. Like all parasites, it may thrive for a time once it finds a yet unexploited organism on which it can feed, but it can't do that without harming the host and sooner or later destroying thereby the conditions of its prosperity, or even of its own survival. [...] Now, a hundred years later, we have come to know that capitalism's strength lies in its amazing ingenuity in seeking and finding (or indeed producing) new species of hosts. $(2009$, p. 20)

Freedom in this sense consists in entrusting our fate to the power of the said economic mechanisms, which we do not really know or maybe even do not control.

Economic freedom relates to political freedom. From a neoliberal perspective, individuals enjoy the inalienable rights to exercise unlimited control over themselves, their products and everything that belongs to them, whereas the state solely performs the role of a "night watchman". The state should grant each person with the inviolability of private property, security and freedom. No one has the right to demand that they sacrifice their own freedom for others. Citizens have only minimum duties towards the rest of society, and they are primarily associated with supporting the states in its efforts to ensure the safety and the protection of private property. Pursuant to the neoliberal views, to live is to recognize the inalienable rights that a legal person has to private property and to a certain rate of profit, and naturally, in the face of the law, a corporation is also considered a per- 
son. One could name numerous examples of the scandalous working conditions and despotism prevalent in large international companies scattered all over the world. In his book, David Harvey cites the story of two young women, employees of a Singapore-based Levi-Strauss subcontractor:

We are regularly insulted, as a matter of course. [...] all of which we have to endure patiently without reacting. We work officially from seven in the morning until three (salary less than $\$ 2$ a day), but there is often compulsory over time, sometimes - especially if there is an urgent order to be delivered - until nine. However tired we are, we are not allowed to go home. We may get an extra 200 rupiah (10 US cents). [...] We go on foot to the factory from where we live. Inside it is very hot. The building has a metal roof, and there is not much space for all the workers. It is very cramped. There are over 200 people working there, mostly women, but there is only one toilet for the whole factory, $[\ldots]$ when we come home from work, we have no energy left to do anything but eat and sleep. (Harvey, 2008, p. 228)

The third way of understanding neoliberal freedom is related to its ideology - the freedom of conscience, the freedom to choose your way of life independently of others, i.e. the ability to establish your own norms as well as the aesthetic, ethical, political and religious values, etc. The ideological freedom presupposes, of course, the autonomy of each entity, and simultaneously, the responsibility of individuals for the ability to think, make decisions and act freely. Yet, history reveals that in practice a person may be only seemingly independent. Karl Marx rightly observes:

The individuals in such a society, although their relations appear to be more personal, enter into connection with one another only as individuals imprisoned within a certain definition, as feudal lord and vassal, landlord and serf, etc., or as members of a caste etc. or as members of an estate etc. (1986, p. 106)

According to the ideology of neoliberal freedom, the unemployed should feel guilty about their state of being unemployed and the poor about their poverty, while in both cases those were the social conditions of life that have contributed to such a situation.

Still, it is not as much about demonstrating that the neoliberal way of understanding freedom is utterly false as about the fact that it manifests internal contradictions when compared how it works in theory and in practice. While developing, this version of freedom creates its own opposition and it is both elusive and unaware of its own contradictions, which are directly caused by the capitalist relations of production.

Neoliberalism rejects Utopianism but it seems to speak of a totally different reality than the one we are experiencing now, at the beginning of the $21^{\text {st }}$ century. The neoliberal rhetoric of the WTO provides a perfect example. The agreement establishing the organization states that all its endeavours should be aimed at: 
raising standards of living, full employment and a large and steadily growing volume of real income and effective demand, and expanding the production of and trade in goods and services while allowing for the optimal use of the world's resources in accordance with the objective of sustainable development, both to protect and preserve the environment and to enhance the means for doing so in a manner consistent with their respective needs and concerns at different levels of economic development. (Harvey, 2008, p. 238)

When the United States tried to force Thailand to use appropriate fishing nets for catching shrimps as those that were being used were destroying the population of the endangered species of sea turtles, the proposal gained unconditional acceptance of the World Trade Organization. Serving as a precedent, this position was defended with an argument that the preservation of the natural environment is too important to allow such actions. In the event of non-compliance with the issued recommendations, Thailand was to have its access to markets suspended. The precedent created in this situation could have been used against the U.S. companies that caused considerable pollution due to greenhouse gas emissions from their production processes. In this case, European countries, Japan and other signatories to the Kyoto Protocol were obliged to reduce or tax the import of U.S. products that contributed to the unnecessary pollution of the atmosphere. And while the conservation of sea turtles is undoubtedly meaningful, the protection of the Earth's atmosphere is of critical importance (Stiglitz, 2007, pp. 191-192).

Even though the outlined problem is surely far more complex and would require further deliberations, basing on the presented evidence it can be concluded that life in the neoliberal world, in which the individual freedom takes on central importance, means accepting — or at least obeying - the laws that are necessary to secure private property and the rates of profit. And yet, these are not the only laws that we can have. Take, for example, the liberal concept of rights presented in the United Nations Charter, such as the freedom of speech and expression, the right to education, to economic security and to forming trade unions, etc.- enforcing them would pose a serious challenge to neoliberalism and would certainly facilitate the implementation of the sustainable development policies.

\section{Amartya Sen on development and freedom}

Without a doubt, Sen's concept of development offers a novel outlook on the way we understand the quality of life and well-being in the settings of the liberal freemarket economy. As stated by the Nobel Prize laureate, the market cannot be the only mechanism regulating development - the cultural determinants should receive more attention. Development should be understood as the process of extending the freedoms that people enjoy. The shortage of basic freedoms may result from (1) economic poverty, (2) the absence of properly functioning social security systems, (3) violations and infringements of political freedoms and civil rights of nations or countries by authoritarian governments. Therefore, to secure freedom, it 
is necessary to eliminate the main sources of unfreedom: poverty, tyranny, limited economic opportunities, systematic social repressions, lack of social security, intolerance or excessive interference of a totalitarian state (Sen, 2002, pp. 17-18).

Sen applies this understanding of freedom to the quality of life category, which in his opinion is shaped by the five basic determinants, and these are (2002, p. 25):

(1) political freedoms - a classical set of freedoms, which constitute the base of modern democracy;

(2) economic opportunities - correspond to economic entitlements, i.e. the guarantees of access to economic resources and the regulations of exchange conditions for implementing them (markets), as assured in the UN Covenants on Human Rights;

(3) social facilities - educational and healthcare institutions that play an important role to the individual participation in political and economic activities;

(4) transparency guarantees - for instance, regulations such as the Act on Access to Public Information or the Act on Public Procurement-the guarantees that are meant to increase the level of trust in interpersonal relations as well as to combat corruption;

(5) protective security-efficient functioning of the social safety net in the form of fixed institutional arrangements (e.g. the unemployment and supplementary benefits), in addition to the ones made on an ad hoc basis (e.g. short-term famine relief or public employment for the unemployed).

These determinants mostly contribute to broadening the scope of opportunities of a given person. Low income is certainly a necessary condition for becoming impoverished, but to a large extent, it is also provoked by limiting the possibilities of individuals. People who have reached a certain level of income but are unable to get a fulfilling job, experience the social isolation, do not receive appropriate health care, cannot reach a satisfactory level of education, or out of necessity live in a polluted environment are, in fact, poor. In Sen's view, it is more important to approach development bearing in mind the possibilities of designing your life in accordance with own desires than just to focus on the world product, technical progress or industrialization. "The relevant freedoms"-writes Sen"include the liberty of actions as citizens who matter and whose voices count, rather than living as well-fed, well-clothed, and well-entertained vassals."

Sen asserts that freedom is not only the essence of development, but it is also one of the elements that determine the quality of life. Unlike John Rawls (1994) for, to whom freedom is the main foundation of justice, or Robert Nozick (1999), who perceives freedom almost as "the measure of all things", Sen does not make such extreme statements. The author of Development as Freedom devotes particularly close attention to the problems of distribution (Becla \& Czaja, 2003, p. 139). In practice, if we want to evaluate well-being in terms of real income, the greatest difficulty results from the diversity of human beings. These include (Sen, 2002, pp. 66-68):

(1) Personal heterogeneities - people differ from each other when it comes to their state of health, physical disabilities, age, sex, all of which translate into distinct needs. The compensations people need vary depending on 
their disability, and in some cases, even additional income will not make any difference. A person suffering from a specific illness will need the resources that are necessary to fight it, whereas a healthy person does not need them at the time;

(2) Environmental diversities - there are also significant variations in our environments: the temperature ranges of a given geographical location, rain falls, the quality of air, etc. All of them are of enormous importance to human behaviour. The heating and the supplies of warm clothing do not improve the quality of life of the poor living in warmer zones;

(3) Variations in social climate - to what degree the personal income and resources affect the quality of life is also influenced by the social conditions, which include: public educational arrangements or the level of crime and violence. Regardless of public solutions, the intensity of community relationships is decisive as well;

(4) Differences in relational perspectives - depending on customs and conventions, there may be clear differences within the community due to the requirements imposed by the existing patterns of interpersonal relations. Being relatively poor in a rich community can exclude an individual from the life of that community, though his or her income may be much higher than the one which allows people in poorer communities to function with much greater ease and success;

(5) Distribution within the family-it should be assumed that the income earned by one family member is normally shared by the whole family, including non-earners. Therefore, the prosperity and freedom of everyone are determined by how the resources of their family are used to support the interests and aspirations of its individual members.

The process of public resources distribution, in which the capabilities and disabilities of individuals are considered, should be subject to control, which in turn relates to transparency guarantees and the access to an appropriate informational base. Such control is effective only if it does not involve distortions, to which Sen (2002, pp. 155-156) includes among others: (1) information distortions, (2) initiatives being discouraged, (3) a sense of disutility and stigmatization, (4) administrative costs, violation of freedoms and corruption, (5) the political instability regarding aid programs and their quality. Ensuring transparency and creating an appropriate informational base is an indispensable element of democracy.

Sen (2002, p. 167) claims that the basic civil liberties and democracy ${ }^{1}$ are of utmost importance and have to be guaranteed since (1) they directly affect the

\footnotetext{
${ }^{1}$ Democracy, of course, meets with no criticism in Europe and America and is undoubtedly one of the basic guidelines for sustainable development. However, as Sen points out, the countries of the Far East name three fundamental arguments against it: firstly, democracy and associated political liberties may pose a threat to economic development (the former Prime Minister of Singapore, Lee Kuan Yew, spoke on the subject); second, in a situation of conflict between democracy and economic security, the people of the East will choose the latter; thirdly, political liberties, freedom and democracy are regarded as typically Western priorities that stand in opposition to "Asian values", which are more oriented to order and harmony rather than to freedom. Amartya Sen asserts that one of the most important values of democracy is its ability to prevent social disasters.
} 
possibilities of human action and they allow to improve the quality of life; (2) they work as a tool that permits people to communicate their needs (including economic ones) and to demand that they are fulfilled; (3) they play a constructive role in identifying needs (also the economic ones).

What is more, according to Sen, the topic of freedom is closely related to the concept of responsibility.

Without the substantive freedom and capability to do something-Sen writes (2002, p. 301) - a person cannot be responsible for doing it. But actually, having the freedom and capability to do something does impose on the person the duty to consider whether to do it or not, this does involve individual responsibility.

The main difficulty that arises with the sense of responsibility is not about following the rules that strictly determine how to behave in a given situation, but about making choices while being convinced of belonging to the community of human beings. Sen points out that the necessity to go beyond the strictly economic rules in considerations on development appears in connection with, for instance, the issue of polluting the natural environment. The natural environment falls within the scope of common goods, i.e. goods the consumers of which are not individual human beings, but whole communities. The existence of public goods at the intersection between the social, the economic and the environmental dimension reveals the necessity for not only the efficiently functioning social control (formal and informal) but, above all, for an adequate system of values and the sense of responsibility. Those are the norms we share that affect such spheres of social life as gender equality, child care, a size and character of a family, treatment of the environment, etc. The problem, however, does not solely lie in creating the rules that strictly specify individual behaviour in particular circumstances but in responsible freedom that relates to the "rational choice".

In the economic and political literature, the rational behaviour-Sen indicates (2002, p. 186) - is commonly understood in the context of decisions whose only motivation is personal gain. Thus, if freedom consists in the sensible pursuit of own benefits, it is not entirely clear why an individual would seek justice and be responsible for the fate of future generations.

Among the factors motivating the actions that go beyond the behaviours aimed at caring only for a narrowly understood self-interest, Sen lists the sympathy for others and the sense of obligation. In the first case, we can be helping another person, for example, because seeing his or her unhappiness brings suffering to us or threatens our own well-being. The actions resulting from sympathy for others do not require giving up on our own interest or limiting our own wellbeing. Yet, in the case of the actions stemming from our sense of obligation, their implementation may necessitate sacrificing one's own good as they require us to be guided by the vision of justice and not by the desire to get ourselves out of an unpleasant emotional state. An action motivated by the sense of obligation does not bring us more benefits or contribute to our well-being. It is most frequently autotelic. 
Summing up, it should be emphasized that Sen deems guaranteeing basic freedoms essential for several reasons: (1) they have a direct impact on the possibilities of human actions and the quality of life, (2) they can be used as instruments to explore human needs and demand their implementation, (3) they are of intrinsic value, which is worth pursuing, and they are a principal source of other values and priorities.

\section{Conclusions}

Amartya Sen may not provide a direct inspiration for the notion of sustainable development, however his ideas offer an intellectual richness upon which the axiological base for this idea can be built. Although the thoughts of Amartya Sen were not a direct inspiration for the idea of sustainable development, they bring invaluable intellectual richness on which the axiological foundation for this idea can be built. Already the Enlightenment philosophy presented freedom either as a degree to which a man manages to control nature or as an extension of civil liberties and freedoms. Whereas the first of the approaches was reflected in a positivist thought derived from the philosophy of Francis Bacon, the second one referred to the whole liberal tradition that originated in the Hobbesian concept of social contract. In both cases, the concept of freedom is applicable to the idea of sustainable development. On the one hand, it emphasizes the freedom of the human race (especially the self-limitations) in the treatment of natural environment; on the other hand, it implies the importance of human self-determination in socio-political context.

Sen's concept of development as freedom proves valuable and useful for the idea of sustainable development because: (1) it allows to analyse the problems of socio-economic development in both developed and developing countries; (2) it provides opportunities to acquire a new perspective on the quality of life, and a better understanding of this idea; (3) it establishes freedom (responsible freedom) as the main category for deliberations about environmental protection and common goods in general. Rawls focus exclusively on the means of achieving the good life: "liberty and opportunity, income and wealth, and the bases of selfrespect" (1994, p. 89). Sen points to the elements that directly make up for a good life. Such indicators as civil and political freedoms, female subjectivity, carbon dioxide emissions, which Sen considered while creating the HDI, are also crucial for maintaining sustainable and continuous development. Both, the concept of sustainable development as well as Sen's understanding of development as freedom are alternative solutions to the neoliberal ideas for development. 


\section{References}

Bauman, Z. (2009). Kapitalizm się chwieje. Le Monde Diplomatique, 3(37).

Becla, A., \& Czaja, S. (2003). Problem jakości życia i dobrobytu w teorii ekonomii (w kontekście badań A. Sena). In J. Tomczyk-Tołkacz (Ed.), Jakość życia w perspektywie nauk humanistycznych $i$ ekologii. Jelenia Góra: Akademia Ekonomiczna we Wrocławiu, Wydział Gospodarki Regionalnej i Turystyki, Katedra Zarządzania Jakością i Środowiskiem.

Bihr, A. (2008). Nowomowa neoliberalizmu. Warszawa: Instytut Wydawniczy Książka i Prasa.

Harvey, D. (2008). Neoliberalizm - historia katastrofy. Warszawa: Instytut Wydawniczy Książka i Prasa.

Marks, K. (1986). Zarys krytyki ekonomii politycznej. Warszawa: Instytut Wydawniczy Książka i Wiedza.

von Mises, L. (1989). Liberalizm w klasycznej tradycji. San Francisco: Cobden Press.

Nozick, R. (1999). Anarchia, państwo, utopia. Warszawa: Wydawnictwo Fundacja "Aletheia".

Płachciak, A. (2010). Sena koncepcja rozwoju jako wolności a idea sustainable development. Annales. Etyka w Życiu Gospodarczym, 13(1), 149-156.

Rawls, J. (1994). Teoria sprawiedliwości. Warszawa: Wydawnictwo Naukowe PWN.

Sen, A. (2002). Rozwój i wolność. Warszawa: Wydawnictwo Zysk i S-ka.

Stiglitz, J. (2007). Wizje sprawiedliwej globalizacji - propozycje usprawnień. Warszawa: Wydawnictwo Naukowe PWN. 